\title{
New and Interesting Records of South African Flowering Plants.
}

\author{
By \\ E. E. A. Archibald, L.E. Codd, R.A. Dyer, \\ A. D. J. Meeuse and D. van Druten.
}

ACANTHACEAE.

Sclerochiton ilicifolius $A$. Meєuse, sp. nov.

Frutex multiramosus, 1-2 m., interdum usque ad $3 \mathrm{~m}$., altus. Rami ramulisque teretes, cortice griseo longitudinaliter pauceque rugoso obtecti; ramuli ulteriores subtereti vel subquadrangulares, laeves, puberuli. Folia parva, rigida, tenuiter coriacea, lucida, subtus pallidiora, oblonga, elliptica vel ovato-elliptica, acuta vel acuminata, pungentia, plerumque pauce spinoso-dentata, interdum parce integra, supra tota subtus ad costam puberula, $1-2 \mathrm{~cm}$. longa et $0 \cdot 6-1 \mathrm{~cm}$. lata; petioli puberuli, $0-3 \mathrm{~mm}$. longi. Inflorescentiae terminales, spicatae, pauciflorae, densae; bracteae bracteolaeque ellipticae, pungentes, integrae vel interdum 1-2 spinas laterales gerentes, dense glanduloso-pubescentes. Calyx extus dense glanduloso-pubescens; sepala 5, inaequalia, pungentia, posterius majus, lineari-oblongum, c. $3 \mathrm{~cm}$. longum, plerumque bicuspidatum; laterales et anteriora lanceolata, longe attenuata, acutissima. Corolla 1-labiata, alba; lobi supra dilutissime violacei, c. $34 \mathrm{~mm}$. longi; tubus brevis, ad apicem contractus, in fauce dense barbatus; limbus cuneato-oblongus, sparse pubescens et intus in lineis longitudinalibus 2 densissime sericeo-villosus, ad apicem 5-lobatis lobis 5 subaequalibus oblongis apice rotundatis leviter deflexis et concavis c. $6 \mathrm{~mm}$. longis. Stamina in fauce inserta, exserta, subaequalia; filamenta arcuata, purpureo-brunnescentia, ad basin pilosa; antherae 1-loculatae, depresse semiorbiculares, lanatae; connectivum ad apicem non productum. Pollen ut in typo, subglobosum. Ovarium cylindrico-fusiforme, glabrum, 4-ovulatum; discus flavus, annuliformis; stylus arcuatus, subulato-filiformis; stigma subnullum minute 2-lobatum. Capsula oblonga vel ellipsoidea, glabra, lignosa, 15-20 mm. longa, 2-4-sperma. Semina subquadrata vel trapezoidea, magis compressa, brunnea, glabra, rugulosa, 5-6 mm. longa.

TransvaAL. - Warm Baths district, hills west of Warm Baths: Mogg s.n.; Waterberg district, between Hermanusdoorns and Elmeston, Meeuse 9655 (type) in National Herbarium, Pretoria; Meeuse 9657, Codd 4011; Soutpansberg district, Schlesinger's Sawmill W. of Louis Trichardt, Gerstner 5929, 1946 (all in PRE; isotypes and duplicates of Meeuse 9657 distributed to BM, BOL, BR, COI, EA, K, L, P, SRGH, and elsewhere).

Description.-Shrub, erect or sometimes somewhat straggly, much branched from the base and throughout, 1-2 m., occasionally up to $3 \mathrm{~m}$. high. Main stems and branches woody, up to about $2 \mathrm{~cm}$. in diam., covered with a greyish longitudinally wrinkled bark; the branches usually bearing numerous short leafy lateral shoots; ultimate twigs terete or faintly quadrangular, firm, yellowish or pale buff to pale yellowish green, smooth, densely puberulous, rather densely leafy mainly towards the apex and many srminating in an inflorescence. Innovations glandular-pubescent. Leaves resembling 
those of the European holly (Ilex aquifolium L.) in shape and texture but smaller, usually oblong or elliptic varying to somewhat ovate or obovate, rather dark green and somewhat shiny above, pale green and duller below, rigid, thinly coriaceous, somewhat tapering to cuneate at the base, acute to acuminate and spine-tipped at the apex, $1-2 \cdot 5 \mathrm{~cm}$. long and $0 \cdot 6-1 \mathrm{~cm}$. wide; the margin slightly thickened to subrevolute, usually with 1-3 spine-tipped triangular teeth on either side, rarely some leaves entire; upper surface glabrous or somewhat puberulous at the base in mature leaves; lower surface glabrous, marked with minute cystoliths, puberulous on the midrib; midrib faintly impressed above, slightly prominent below; lateral nerves (3-)4-7(-8) on either side, hardly impressed above, in fresh leaves impressed but in dried specimens prominent on lower surface, emerging at an angle of about $45^{\circ}$, rather straight, mostly reaching the margin and some of them ending in the thin spine of a lateral tooth of the leaf-blade; tertiary nervation inconspicuous; petioles $0-3 \mathrm{~mm}$. long, somewhat depressed above, convex below, puberulous. Inflorescences terminal on the flowering branches, spicate, ovoid or shortly cylindric, 4-6 flowered; upper leaves gradually changing into a few lower sterile bracts; sterile and fertile bracts entire or occasionally with a lateral spine on one or both sides, ovate or ovate-elliptic to somewhat obovateelliptic, slightly concave, acuminate and spine-tipped, in colour and texture resembling the leaves but slightly paler and densely covered with fine gland-tipped patent hairs intermixed with shorter non-glandular hairs on outer (lower) side, on their margins and on their tips inside, and on lower half of inner (upper) surface with some short adpressed hairs, 20-25 $\mathrm{mm}$. long and about $10 \mathrm{~mm}$. wide; main nerve ending in the terminal spine and on either side with 1-3 nerves arising from the base and running more or less parallel with the main nerve, all reaching the margin in upper half of the bract; bracteoles 2, very similar to the bracts but slightly narrower, 7-8 $\mathrm{mm}$. wide. Calyx green, unequally 5-lobed, the lobes ending in soft spines, densely glandular, pubescent outside and near the tips inside, upper (posticous) lobe the largestlinear-oblong, acute to acuminate and undivided, or more or less deeply bicuspidate with acute, spine-tipped cusps at the apex, about $3 \mathrm{~cm}$. long and $6.5 \mathrm{~mm}$. wide; 2 lateral lobes linear-lanceolate, long-tapering into a very acute apex, about $2.5 \mathrm{~cm}$. long and 2-2.5 mm. wide near the base; basal (anticous) lobes linear-lanceolate, tapering into an acute apex, $26 \mathrm{~mm}$. long and $3-3.5 \mathrm{~mm}$. wide near the base. Corolla white tinged with very pale mauve on the inside of the lobes and more creamy-white on lower side of lip, $34 \mathrm{~mm}$. long, tube short, smooth, shiny, glabrous outside, cylindriccampanulate, thence widening into an oblique throat which is partly covered with soft white adpressed hairs outside, mainly on upper side, and densely bearded within; limb large, 1-lipped, cuneate-oblong, sub-equally 5-lobed, about $25 \mathrm{~mm}$. long and $21 \mathrm{~mm}$. wide near the apex, nearly glabrous below, with a few short hairs and two very densely white-silky palatal ridges extending from the throat to the corolla-lobes on upper (inner) side; the lobes oblong, rounded at the apex. Stamens 4, subequal, inserted in the throat in two pairs, filaments brown, densely bearded at the base and 2 upper (posticous) ones thinly hairy throughout, about $15 \mathrm{~mm}$. long; anthers 1-thecous, depressed semi-orbicular, completely attached to the filament, yellowish brown, those of each pair more or less connate by woolly hairs; connective greenish. Pollen subglobose, smooth, with three longitudinal very shallow chinks not reaching the poles. Pistil about $19 \mathrm{~mm}$. long; disc annular, bright yellow; ovary ovoid-oblong, rather dark green, glabrous, 4-ovuled; style subulate-filiform, rather stout, slightly upcurved in basal part, thence faintly arcuate-recurved, very pale mauvish green with a line of white hairs near its base on lower (abaxial) side otherwise glabrous; stigma truncate, faintly bilobed. Capsule oblong or ovoid-oblong, somewhat laterally compressed, tapering to apiculate at the apex, turning a shiny brown when ripe, woody, 15-20 mm. long. Seeds 2-4, much compressed, subquadrate or trapezoid often more or less distinctly oblique or produced on one side at the base, brown when ripe, finely rugose, without hygroscopic hairs, 5-6 $\mathrm{mm}$. long. 


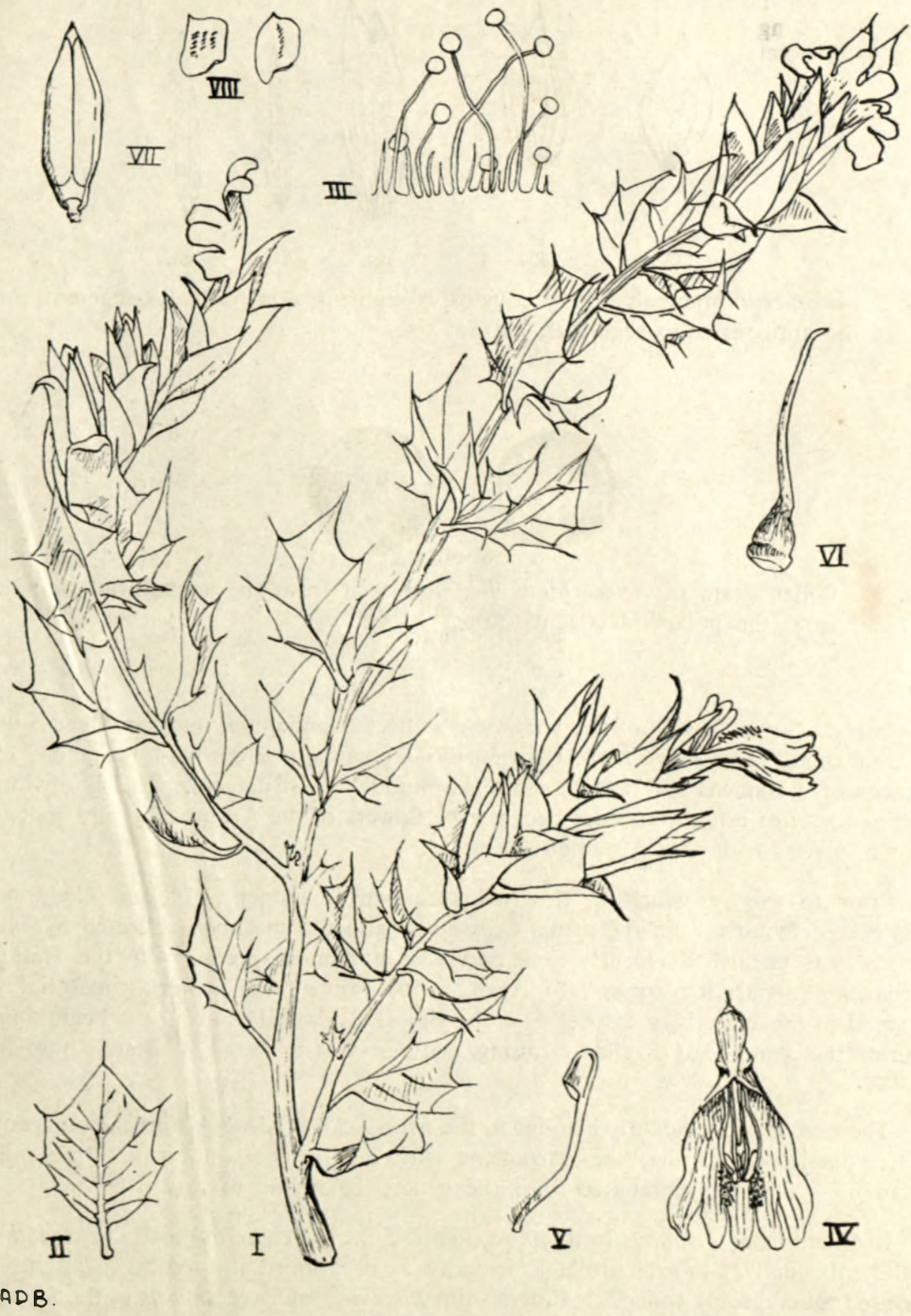

Fig. 1.-Sclerochiton ilicifolius flowering branch; 2, leaf; 3, pubescence of floral leaves and calyx, showing gland-tipped hairs and short non-glandular ones; 4, corolla, seen from above; 5 , stamen, seen from the side; 6 , pistil; 7 , capsule and 8 , seeds. 1, 2 and 4: natural size. 5, 7 and 8: $\times 1 \cdot 5,3, \times 100$ and $6, \times 2$. 


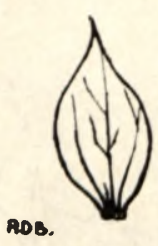

a.

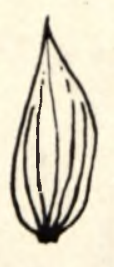

b.

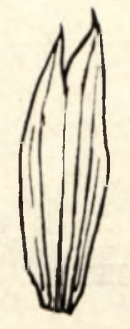

c. d.

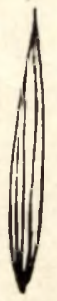

e.

Fig. 2. $-a$ bract, $b$ bracteole, $c$ posticous calyx-segment, $d$ lateral calyx-segment, $e$ one of the anticous calyx-segments, natural size.
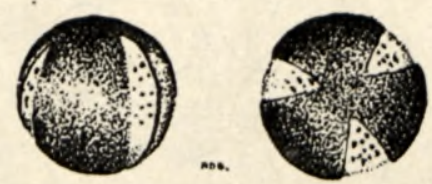

FIG. 3.-Pollen grain of Sclerochiton ilicifolius seen from the aequatorial side (left) and from the polar side (right), appr. $\times 400$.

NoTE.-Some flowers of the specimens collected under the number Meeuse 9655 are abnormal. They have more than 5-calyx-segments, 6-9 corolla-lobes and 5 or 6 stamens or 4 stamens and 1 or 2 sterile staminode-like structures. This is obviously a monstrosity or a teratologicum because the flowers of the Acanthaceae are generally 4 - or 5 -merous with 4 or 2 stamens.

Prior to this investigation the two specimens Gerstner 5929 and Codd 4011 were placed tentatively in the genus Crossandra and the specimen collected by Mogg in 1924 was unearthed recently in a parcel of unnamed specimens in the National Herbarium preparation room. In April, 1955, ample fresh flowering material was obtained in the Waterberg district near the site of Codd 4011 and in the beginning of June of the same year excellent fruiting material was collected in exactly the same locality.

The new species evidently belongs to the tribe Acanthoideae-Acantheae on account of the one-lipped corolla, the 4 stamens with one-loculed anthers and the pollen morphology and was compared with the genera belonging to this tribe.

It differs from Acanthus in its habit, in the 5-partite calyx (4-partite in Acanthus), in the subequally 5-lobed corolla (unequally 3- or 5-lobed in Acanthus) and in the globose (not ellipsoid) pollen. It differs from Blepharis and Acanthopsis in the 5-partite calyx, the sub-equally 5 -lobed corolla, the pollen and the glabrous seeds (the seeds have hygroscopic hairs in the other two genera); in addition, Blepharis has the filaments of the anticous segments produced behind the anthers and the ovary has 2 hollows filled with glands. 
It differs from Crossandra, among other things, in the short corolla-tube (long in Crossandra), in the colour of the corolla (red, orange or yellow in Crossandra), in the exserted stamens (included in Crossandra), in the shape of the pollen and in the glabrous seeds (those of Crossandra are covered with hygroscopic hairs or with scales fringed with hygroscopic hairs). It was evident that the plant agreed with the genus Sclerochiton (including Pseudoblepharis) in all essential characters such as the shape of the inflorescence, the 5-partite calyx, the subequally 5-lobed corolla, the morphology of the stamens and pollen, the stigma and the glabrous seeds. It differs from all previously described species of Sclerochiton in a few less important, mainly vegetative characters such as the spine-toothed and pungent leaves, the pungent floral leaves and calyx-segments and the glandular pubescence on the floral leaves and calyx. The leaves in all other species are entire, although those of the type species, Sclerochiton harveyanus Nees, are sometimes faintly crenate or serrate. Pungent floral leaves and calyx segments, and a glandular pubescence were also not previously recorded for this genus. These differences do not, however, warrant separate generic status. All descriptions of species of Sclerochiton, a genus restricted to Africa and Madagascar, were compared and not one is even remotely suggestive of the species discussed here. No other genus proposed in the tribe Acantheae from Africa or Madagascar was encountered that could possibly fit our plant, so that it is most unlikely that it was ever described before. A specimen was kindly compared by Dr. H. Wild of the Government Herbarium, Salisbury, Southern Rhodesia, who reported that he did not know the plant and that it was not represented in the Salisbury herbarium. This would indicate that the plant does not occur in tropical Africa and is restricted to the Transvaal. Its known distribution in the Transvaal is very scattered, and although the plant, even when not in flower, is rather remarkable with its bright green foliage consisting of small spine-toothed leaves and would attract the attention of botanists on the solid quartzite outcrops forming its natural habitat, it must be a rare or very local species. On the other hand it can be quite frequent locally. The leaves, though smaller, are strongly reminiscent of those of the European holly, Ilex aquifolium L., and the specific epithet "ilicifolius" is considered to be appropriate as it not only expresses this resemblance but also emphasizes one of the main differences between the new species proposed here and all other species of Sclerochiton.

\section{ANACARDIACEAE.}

Rhus batophylla $L$. $E$. Codd, sp. nov., affinis $R$. tomentosae L. foliolae marginibus in toto serrato-dentatis, ramulis infra foliisque dense lanatis, inflorescentiis longioribus et angustioribus differt.

Frutex 1-1.5 m. altus e basi profunde ramosus. Rami ascendentes, sparse ramosi, superne dense lanati. Folia petiolata, petiolis $1-2 \mathrm{~cm}$. longis, supra leviter canaliculatis, dense lanatis; foliolae sessiles, ellipticae, ovatae vel obovatae, coriaceae, serratodentatae, dentibus triangularibus mucronatis $2-3 \mathrm{~mm}$. longis basi $3-4 \mathrm{~mm}$. latis, infra dense tomentosae, supra glabrescentes; foliola terminalis $4 \cdot 5-6 \cdot 5 \mathrm{~cm}$. longa, $2 \cdot 3-3 \mathrm{~cm}$. lata, foliolae laterales $2 \cdot 5-3 \cdot 8 \mathrm{~cm}$. longae, $1 \cdot 5-2 \cdot 6 \mathrm{~cm}$. latae. Paniculae terminales vel non-nunquam axillares, angustae, $8-18 \mathrm{~cm}$. longae, $2-4 \mathrm{~cm}$. latae, dense lanatae. Flores aggregati, pedicellis $0.5-1 \mathrm{~mm}$. longis; sepala triangularia, plusminusve $0.7 \mathrm{~mm}$. longa; petala glabra, 1-1.5 mm. longa, in floribus masculis staminibus 5 brevioribus. Drupae compressae, 5-6 mm. latae, glabrae, rubrae.

Plate No. I.

TransvaAl.-Lydenburg District, Sekukuniland: Mogg s.n.; Mooihoek Chrome Mine, $1 \frac{1}{2}$ miles west of Driehoek, Codd and Dyer 7699, female (type), 7700, male; Story 4051; 5 miles south-east of Steelpoort Post Office, Codd 6700. 
Shrub 1-1.5 m. high, branching freely from the base. Branches stiff, ascending, sparingly branched, unarmed, the younger branches densely lanate, with reddish-brown bark under the tomentum. Leaves trifoliolate, petiolate; petioles $1-2 \mathrm{~cm}$. long, slightly channelled on the upper surface, not winged, densely lanate; leaflets sessile, elliptic to ovate or obovate, obtuse to cuneate at the base, acute, coriaceous, tending to fold along the midrib, regularly and conspicuously serrate-dentate from base to apex, the teeth broadly triangular, mucronate, 2-3 $\mathrm{mm}$. long and 3-4 $\mathrm{mm}$. broad at the base; under surface of leaf covered with dense, white to cream coloured, woolly, persistent tomentum, the upper surface covered thinly in the young stage, becoming glabrescent with age; secondary nerves prominent on under surface; tertiary nerves reticulate above, obscured by the tomentum below in the young stage but becoming conspicuous with age; terminal leaflet $4 \cdot 5-6 \cdot 5 \mathrm{~cm}$. long and $2 \cdot 3-3 \mathrm{~cm}$. broad with 8-12 pairs of secondary nerves; lateral leaflets $2 \cdot 5-3 \cdot 8 \mathrm{~cm}$. long and $1.5-2.6 \mathrm{~cm}$. broad with 6-9 pairs of secondary nerves. Inflorescence terminal and also axillary in the upper leaf axils, forming a narrow, elongate panicle $8-18 \mathrm{~cm}$. long and $2-4 \mathrm{~cm}$. wide, the main axis and branchlets densely lanate tomentose. Flowers borne in clusters; pedicels 0.5-1 mm. long. Calyx pubescent, 5-partite, segments triangular, less than $1 \mathrm{~mm}$. long. Corolla glabrous, yellow-green; petals 5, 1-1.5 mm. long. Male flowers with 5 stamens, shorter than the petals; disc present; ovary absent. Female flowers usually with 5 staminodes; ovary flattened. Drupe glabrous, flattened, 5-6 $\mathrm{mm}$. long, red and wrinkled when mature.

Rhus batophylla is a very distinctive shrub showing no close affinity to any known species. The dense, woolly tomentum persisting on the branchlets and on the underside of the leaves suggests that its relationship is to Schonland's section Tomentosa, but it is readily distinguished from any species in this group and, in fact, from any other South African species, by the margins of the leaflets being regularly serrate-dentate from base to apex, and in the long, sparingly branched, narrow inflorescence. Specimens were sent to our liaison officer at the Kew Herbarium, where they were unmatched.

With its discolorous, markedly serrate leaflets and its habit of branching near ground level, producing numerous stiff, ascending branches 3 to 4 feet high, the plants bear a striking resemblance to a species of Rubus, and the specific epithet is derived from the Greek batos, bramble. The plants tend to grow communally in the dry bushveld to the north and west of Burgersfort, in eastern Sekukuniland, where the altitude is about 3,000 feet. The species has not been recorded outside this area.

\section{ASCLEPIADACEAE.}

Brachystelma montanum, $R$. A. Dyer, sp. nov., affinis $B$. crispo Grah., sed habitu minore corollis multo minoribus interne immaculatis externe glabris differt.

Herba perennis; tuber $2-5 \mathrm{~cm}$. latus, plus minusve $2 \mathrm{~cm}$. altus, subglobosus vel depresso-globosus. Caules perennes, subterranei, solitarii vel bini, ad $5 \mathrm{~cm}$. longi, caules annui 1-4, usque ad $6 \mathrm{~cm}$. alti, superne ramosi. Folia oblonga ad linearilanceolata, basalia $1 \cdot 5-2 \cdot 3 \mathrm{~cm}$. longa, $2-4 \mathrm{~mm}$. lata, superiora breviora et angustiora obtusa ad acuta, infra et marginibus scabrida, supra tenuiter scabrida. Flores ad nodos plerumque 2 , pedicelli graciles, $1-3.5 \mathrm{~mm}$. longi, dorso pilis paucis instructi. Corolla usque ad $1.5 \mathrm{~cm}$. longa, basi tubulosa; tubus campanulatus, usque ad $4.5 \mathrm{~mm}$. longus, 4-5 mm. diametro; lobi e basi ovato-lanceolato lineares, circiter $1 \mathrm{~cm}$. longi, minus $1 \mathrm{~mm}$. lati, infra medium ciliati. Coronae lobi inferne in seriei uno confluentes, exteriores poculos V-formatos formantes, interiores supra incumbentes, partibus liberis linearibus usque ad $1 \mathrm{~mm}$. longis. 
Cape Province.-Wodehouse Division, northern slopes of Andriesberg, 6,000 ft. Dec. Galpin 6278 in National Herbarium Pretoria, type (duplicate at Kew).

Perennial herb; tuber $2-5 \mathrm{~cm}$. broad and about $2 \mathrm{~cm}$. thick, subglobose or depressed, with 1-2 perennial underground stems up to $5 \mathrm{~cm}$. long; annual branches $1-4$, up to $6 \mathrm{~cm}$. tall, branched above. Leaves oblong to linear-oblong; basal ones $1 \cdot 5-2 \cdot 3 \mathrm{~cm}$. long, $2-4 \mathrm{~mm}$. broad and upper ones considerably reduced in size. Flowers usually 2 from each node; pedicels slender $1-3.5 \mathrm{~cm}$. long, thinly pubescent. Sepals lanceolate, 3-3.5 mm. long with a few hairs on their backs. Corolla up to $1.5 \mathrm{~cm}$. long, tubular at base; tube campanulate, up to $4.5 \mathrm{~mm}$. long and $4-5 \mathrm{~mm}$. diam. at the mouth; lobes linear from an ovate-lanceolate base, about $1 \mathrm{~cm}$. long, less than $1 \mathrm{~mm}$. broad above, ciliate below the middle. Corona lobes united more or less into one series about $2 \mathrm{~mm}$. high; the outer lobes are like V-shaped pockets with their margins appearing as shoulders at the base of the inner lobes; inner lobes incumbent on the backs of the anthers with the free portion linear, up to $1 \mathrm{~mm}$. long.

Galpin's specimen has remained unnamed since its collection in 1901. It is well known that the flowers of Stapelieae and of allied genera such as Brachystelma shrivel during drying unless particular care is taken to prevent it. In the case of Galpin 6278 parts of the collection have obviously contracted considerably in drying while others appear to have retained their normal size and the measurements given above were taken from these.

Brachystelma pilosum $R$. A. Dyer, sp. nov., affinis B. galpinii N.E. Br., sed robustior, pilis patulis hirsuta, coronae lobis exterioribus glabris, coronae lobis interioribus oblongis obtusis differt.

Herba perennis, erecta usque ad $25 \mathrm{~cm}$. alta, prope basin ramosa, pilis patulis 1-1.5 mm. longis hirsuta. Caulis basi $4-5 \mathrm{~mm}$. diametro; internodiis $2-4 \mathrm{~cm}$. longis. Folia sessilia vel subsessilia, oblonga, $1-1 \cdot 5 \mathrm{~cm}$. longa, $3-5 \mathrm{~mm}$. lata, marginibus satis involutis et leviter undulatis. Flores patentes vel suberecti, plerumque 2 ad nodos. Sepala lanceolata, 2-2.5 mm. longa. Corolla $1 \cdot 6-1 \cdot 8 \mathrm{~cm}$. longa, parte inferiore patelliformi $1-1.5 \mathrm{~mm}$. connata, lobi basi lanceolati, medio ad $0.5 \mathrm{~mm}$. contracti, superne ad $1 \mathrm{~mm}$. lati, apicibus connati, externe dimidio inferiore, superne tenuiter hirsuti, interiore glabri. Corona columnae staminalis supra basin circiter $0.75 \mathrm{~mm}$. inserta; coronae lobi exteriores $1.5 \mathrm{~mm}$. longi, in segmentis linearibus profunde bilobati; coronae lobi interiores oblongi, supra antheras incumbentes et leviter longiores, basin versus dorsale leviter umbonati.

TransvaAL.-Potgietersrust Division; near Naboomspruit on farm Nooitgedacht in lightly wooded grassland, rare, July, Galpin 11573 in National Herbarium, Pretoria, type; Crawley, Transvaal Mus. No. 10402, at Kew and N.H.P.

Perennial herb, erect, up to about $25 \mathrm{~cm}$. tall, branched from near the base. Stem 4-5 mm. diam. near base; branches hirsute with spreading hairs $1-1.5 \mathrm{~mm}$. long; internodes $2-4 \mathrm{~cm}$. long. Leaves sessile or subsessile, more or less oblong, $1-1 \cdot 5 \mathrm{~cm}$. long, 3-5 mm. broad, with the margins somewhat folded upwards and slightly undulate. Flowers spreading or suberect, usually 2 together at the nodes. Sepals lanceolate, $2-2 \cdot 5 \mathrm{~mm}$. long. Corolla $1 \cdot 6-1 \cdot 8 \mathrm{~cm}$. long, with the basal united portion saucer-shaped, 1-1.5 mm. long; lobes united at tips with a lanceolate base and contracted to $0.5 \mathrm{~mm}$. then expanded towards the tips to $1 \mathrm{~mm}$. broad, hirsute on the backs in the lower half and thinly so above, glabrous on the inner surface. Corona arising from the staminal column about $0.75 \mathrm{~mm}$. above its base; outer corona lobes about $1.5 \mathrm{~mm}$. long, deeply bilobed into linear segments; inner corona lobes oblong, incumbent on the backs of the anthers and slightly exceeding them but not meeting over the centre of the staminal column, slightly thickened or humped on the backs towards the base. 
In Kew Bulletin 1953 p. 358, Mr. Bullock proposes the resuscitation of the genus Dichaelia Harv. for the species of Brachystelma in which the tips of the corolla-lobes are connate. In describing $B$. pilosum, which has this character, I have followed N. E. Brown and used the generic name Brachystelma because I consider the observations by Brown in Fl. Cap. 4, 1: 834 (1908) are well founded and his treatment consistent with the known facts.

\section{LILIACEAE.}

Albuca crudenii, Archibald sp. nov., affinis A. glandulosae, Bak., folio uno, perianthio glabro, stigmate convexo differt.

Bulbus subglobosus, circiter $30 \mathrm{~mm}$. diam., membranaceo-tunicatus. Folium unum, viridi-flavum, lineario-lanceolatum, planum vel paulum plicatum, usque ad $45 \mathrm{~cm}$. longum, $16 \mathrm{~mm}$. latum, novellum apice subulato, marginibus venisque puberulis. Scapus $45 \mathrm{~cm}$. longus, puberulus; pedunculus $28 \mathrm{~cm}$. longus, $3 \mathrm{~mm}$. diam.; racemus laxus secundus; bracteae membranaceae, rubro-nervatae, deltoideae, apiculatae, $9 \mathrm{~mm}$. longae, $8 \mathrm{~mm}$. latae; pedicelli cernui, puberuli. Flores 3-10, penduli, odorati; petala exteriora glabra, patentia, aurea, medio viridi-striato, oblonga, $15 \mathrm{~mm}$. longa, $6 \mathrm{~mm}$. lata, apicibus haud cucullatis; petala interiora glabra, erecta, colore pallidiora quam exteriora, ovata, $12 \mathrm{~mm}$. longa, $5 \mathrm{~mm}$. lata, apicibus cucullatis $1 \mathrm{~mm}$. longis. Stamina exteriora infertila, interiora fertila. Gynoecium glabrum; ovarium $5 \mathrm{~mm}$. longum, $3 \mathrm{~mm}$. diam., viride, basin versus sine scuta; stilus oblongus, $5 \mathrm{~mm}$. longus, $1 \mathrm{~mm}$. diam., luteus; stigma convexum, viride.

CaPe Province.-Albany District: Dassieklip, October, Archibald 5289 in Albany Museum Herbarium (type); Alicedale, September, Cruden 14a in Albany Museum Herbarium.

Bulb nearly spherical, up to $30 \mathrm{~mm}$. diam.; scales tunicate, outer light brown, membranous, inner white, fleshy; roots fibrous. Leaves usually one, only very rarely two, light yellowish-green, lax, mesophytic, linear-lanceolate, flat or slightly folded, up to $45 \mathrm{~cm}$. long, $16 \mathrm{~mm}$. broad, tip subulate in young leaf but withering off early, veins marked on upper and lower surfaces by fine channels, leaf margins and vein-channels each with a single row of minute, glandular, transparent, erect hairs. Inflorescence a lax, secund raceme up to $45 \mathrm{~cm}$. long; peduncle up to $28 \mathrm{~cm}$. long, $3 \mathrm{~mm}$. diam., with minute, sparsely distributed, glandular hairs in inconspicuous channels, raceme a quarter to half as long as peduncle, similarly puberulus, bracts deltoid, apiculate, up to $9 \mathrm{~mm}$. long, $8 \mathrm{~mm}$. broad at base, membranous, transparent, with several light reddish-brown veins; pedicels cernuous, becoming erect as fruit ripens, lowest up to $20 \mathrm{~mm}$. long becoming shorter towards apex of raceme, puberulus. Flowers 3-10, pendulous, with faint vanilla-like scent. Perianth glabrous; outer segments up to $15 \mathrm{~mm}$. long, $6 \mathrm{~mm}$. broad, patent, oblong, with very slightly cucullate apex, bright yellow with narrow green median stripe; inner segments up to $12 \mathrm{~mm}$. long, $5 \mathrm{~mm}$. broad, erect, connivent, ovate, pale yellow with narrow green median stripe, apex cucullate, $1 \mathrm{~mm}$. long. Androecium three sterile and three fertile stamens; outer filaments ovate-lanceolate, up to $9 \mathrm{~mm}$. long, $1.5 \mathrm{~mm}$. broad, with mucronate, sterile tip; inner filaments spade-shaped, lower part $1.5 \mathrm{~mm}$. long, $1.5 \mathrm{~mm}$. broad, upper part $5.5 \mathrm{~mm}$. long, less than $1 \mathrm{~mm}$. broad; anthers $4 \mathrm{~mm}$. long, apex rectangular, base spreading. Gynoecium glabrous; ovary ellipsoidal in longitudinal section, carpels rounded dorsally, without basal shields, $5 \mathrm{~mm}$. long, $3 \mathrm{~mm}$. diam., green; style oblong with slightly narrower section in upper third, triquetrous, $5 \mathrm{~mm}$. long, $1 \mathrm{~mm}$. diam, yellow; stigma convex, 3-lobed, lobes simple each with a row of minute papillae, green. Fruit a trilocular capsule, apex acute when green; seeds numerous. 


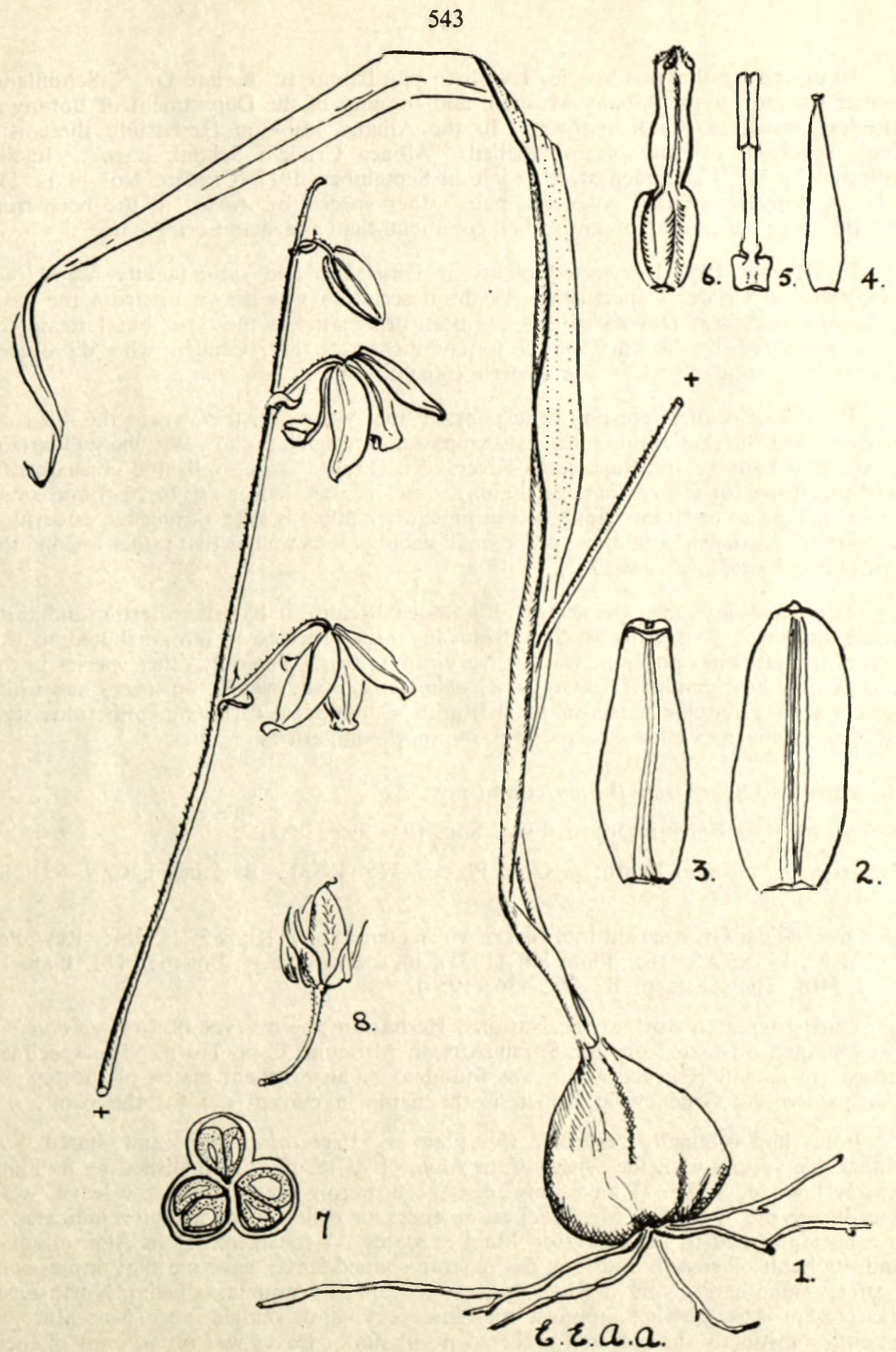

FIG. 4.-1, Albuca crudenii; 2 and 3, outer and finner perianth segments; 4 and 5, sterile and fertile stamens; 6 , gynoecium; 7,4 cross-section of ovary; 8 , developing fruit. 
In describing this new species I wish to pay tribute to the late Dr. S. Schonland, former Curator of the Albany Museum and founder of the Department of Botany at Rhodes University, Grahamstown. In the Albany Museum Herbarium there is a single specimen of this species labelled "Albuca Crudeni Schonl. n.sp.". It was collected by Mr. F. Cruden at Alicedale in September, 1917 (Cruden, No. 14a). Dr. Schonland made copious notes on many other species of Albuca in the herbarium but this sheet is devoid of any other comment than the manuscript name.

In October 1953 I collected plants at Dassieklip and subsequently found that they matched Cruden's specimen. As the description was drawn up from the fresh material collected at Dassieklip this has been designated as the type, but I retain the name suggested by Dr. Schonland to commemorate Mr. Cruden who discovered several interesting plants in the eastern Cape Province.

Dassieklip is an interesting little poort in the Albany District where the old road between Port Elizabeth and Grahamstown passes through a fault of Witteberg Quartzite on the east bank of the Bushman's River. The krantz faces south and consequently is in the shade for a large part of the day. On its rock ledges are to be found small ripens, lowest up to $20 \mathrm{~mm}$. long becoming shorter towards apex of raceme, puberulus. colonies of $A$. crudenii and many other small geophytes as well as that rather uncommon fern Ophioglossum nudicaule, L.f.

A. crudenii falls into the section Eu-albuca because it has three fertile and three sterile stamens. It is quite distinct from any other species so far attributed to this section in that it has only one leaf, or, very rarely, two. The only other species in the section that has glandular leaves is $A$. glandulosa, Bak. which, however, has white flowers with glandular hairs on the perianth segments, a turbinate, puberulus style and flat stigma as well as many other minor dissimilarities.

Aloe alooides (Bolus) van Druten comb. nov.

Urginea alooides Bolus in Journ. Linn. Soc. 18: 395 (1881).

Notosceptrum alooides Benth. in Gen. Pl. 3: 775 (1883); Bkr. in Fl. Cap. 6: 285 (1897).

Aloe recurvifolia Groenewald in Tydskrif vir Wetenskap en Kuns 39 (1935); Reynolds in Fl. Pl. S. Afr. 16: Plate 801 (1935), in Journ. of S.A. Bot. 6: 111, Plate 10 (1940), The Aloes of S. Afr. 436 (1950).

During research work at the National Herbarium the iso-type of Urginea alooides was obtained on loan from the South African Museum, Cape Town. The specimen consists of an inflorescence which was found to be an excellent match of the type of Aloe recurvifolia Groenewald, which is the name in current use for the plant.

Bolus had originally described this plant as Urginea alooides and stated " A remarkable species with the aspect of an Aloe. It is readily distinguished by its long densely flowered spike. I have only seen the flowering scapes; but the leaves were described to me by the late Mr. MacLea, an energetic collector in the region indicated". In a note attached to his collection MacLea states "I considered it an Aloe of some kind, its habit of growth and long fleshy strap-shaped leaves gave me that impression. It affects same habit as most Aloes, grows on slopes of mountains facing North-East. The present was growing amongst quartzite rock and shingle near Mac-Mac. I remember distinctly the reason I gathered no plants or leaves was on account of their size and thick fleshy nature-not so sure about the leaves being strap-shaped or linear-lanceolate. I think they were the former and pendulous at the extremities and not less than $2 \mathrm{ft}$. long. More than one flower spike to each plant." It seems strange 
that, with this information, Bolus should have placed the plant in the genus Urginea but he apparently ruled out the genus Aloe because of the very small-flowered dense spike.

In his Genera Plantarum Bentham transferred Bolus's species to his new genus Notosceptrum and it was retained there, tentatively, by Baker in Flora Capensis. Nothing further was done until the present investigation, and although it is unfortunate that so apt a specific epithet as recurvifolia must be changed, there is no doubt that the plant must bear the name Aloe alooides.

\section{VITACEAE.}

Cissus natalitia (Szysz.) L. E. Codd, comb. nov.

Vitis natalitia Szysz., Polypet. Rehmann., 2: 45 (1889).

Cissus connivens Lam. var. meyeriana Planch. in DC. Monog. Phan. 5: 584 (1887), partly; Gilg and Brandt in Engl. Bot. Jahrb. 46: 516 (1912), partly; Suessenguth in Pflanzenfam. 20d: 250 (1953), partly.

C. glabra E. Mey. in Drège, Zwei Pfl. Docum. 173 (1843), nomen nudum; Planch. l.c. 584 , in synonomy.

C. orientalis Harv. in Fl. Cap. 1: 253 (1859/60), partly, non Lam.

The specimens cited by Szyszylowycz are as follows:-

NaTAL.-Ladysmith, Rehmann 7136; Biggarsberg, Rehmann 7098; Vildshill, Pinetown, Rehmann 7991.

In Flora Capensis, Harvey mis-identified two specimens as Cissus orientalis Lam., namely, Drège, from between the Umtata and Umzimvubu Rivers, and Burke and Zeyher, from the Magaliesberg. Planchon placed the two specimens under $C$. connivens Lam. var. meyeriana Planch., a treatment followed by Gilg and Brandt, while the species $C$. orientalis Lam. he removed to the genus Ampelocissus. A study of available herbarium material, together with observations in the field, led to the conclusion that these specimens are representative of two distinct species.

The Burke and Zeyher specimen was given specific rank as $C$. sulcatus C. A. Smith in Burtt Davy's Flowering Plants and Ferns of the Transvaal and Swaziland, 2: xx, 477 (1932). Thus the question arose as to whether a specific name was available for the Drège specimen. Judging by the localities and descriptions, it seemed probable that it would prove to belong to the same species as the Rehmann specimens described as Vitis natalitia Szysz., and this view was confirmed by our liaison officer at the Kew Herbarium.

A comparison between the species $C$. sulcatus, $C$. natalitia and $C$. connivens was made possible through the kindness of the Director of the Muséum National d'Histoire Naturelle, Paris, who sent us a portion of Lamarck's type on loan. The conclusion reached is that $C$. sulcatus is more closely related to $C$. connivens than is $C$. natalitia and that, while there are sufficient grounds for regarding $C$. natalitia as a good species, more material is required from Madagascar, the type area for $C$. connivens, for a correct evaluation to be made of the status of $C$. sulcatus. In separating $C$. sulcatus from C. connivens, C. A. Smith 'states very briefly that his species differs in the multipinnate not bipinnate leaves, and in the fruits, though he fails to indicate how the fruits differ. In the present state of our knowledge, the three species may be distinguished as in the following key:-

Stipitate glands usually present; leaflets regularly dentate from base to apex; stems

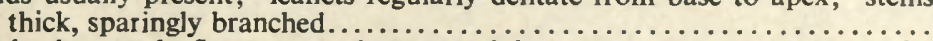

Stipitate glands absent; leaflets crenate-dentate mainly towards the apex; stems thin, much branched

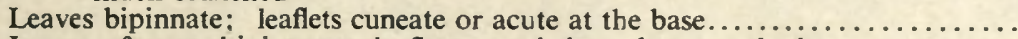

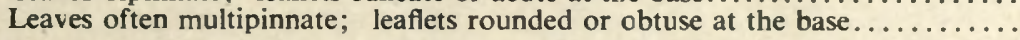

C. natalitia.

C. connivens.

C. sulcatus. 
C. natalitia is distributed from northern Natal to the Transkei and, in addition to the Drège and Rehmann specimens mentioned previously, is represented by the following specimens:-

Natal.-Ngotshe, Codd 7024. Nongoma, Gerstner 718. Hlabisa, Codd 2010. Nqutu, Codd 2401. Dundee, van der Merwe 2649. Klip River, Acocks 13855. Weenen, Medley Wood 10132; Acocks 10709. Eshowe, Gerstner 2406. Mtunzini, Mogg 5909, 6013. Pietermaritzburg, Killick 262; Codd 6795. Camperdown, McClean 143. Port Shepstone, Galpin 11012.

CAPE.-Port St. Johns, Howlett 43; Bruce 451. Kentani Pegler 890.

C. sulcatus is so far recorded only from the central Transvaal, as indicated by the following collections:-

Transvaal.-Brits, Hutchinson 2326; C. A. Smith 3443; Mogg s.n.; Hofmeyr s.n.; Leendertz 713. Rustenburg, Codd 6364; Pole Evans s.n; Waterberg, van Son in TM. 30435. 


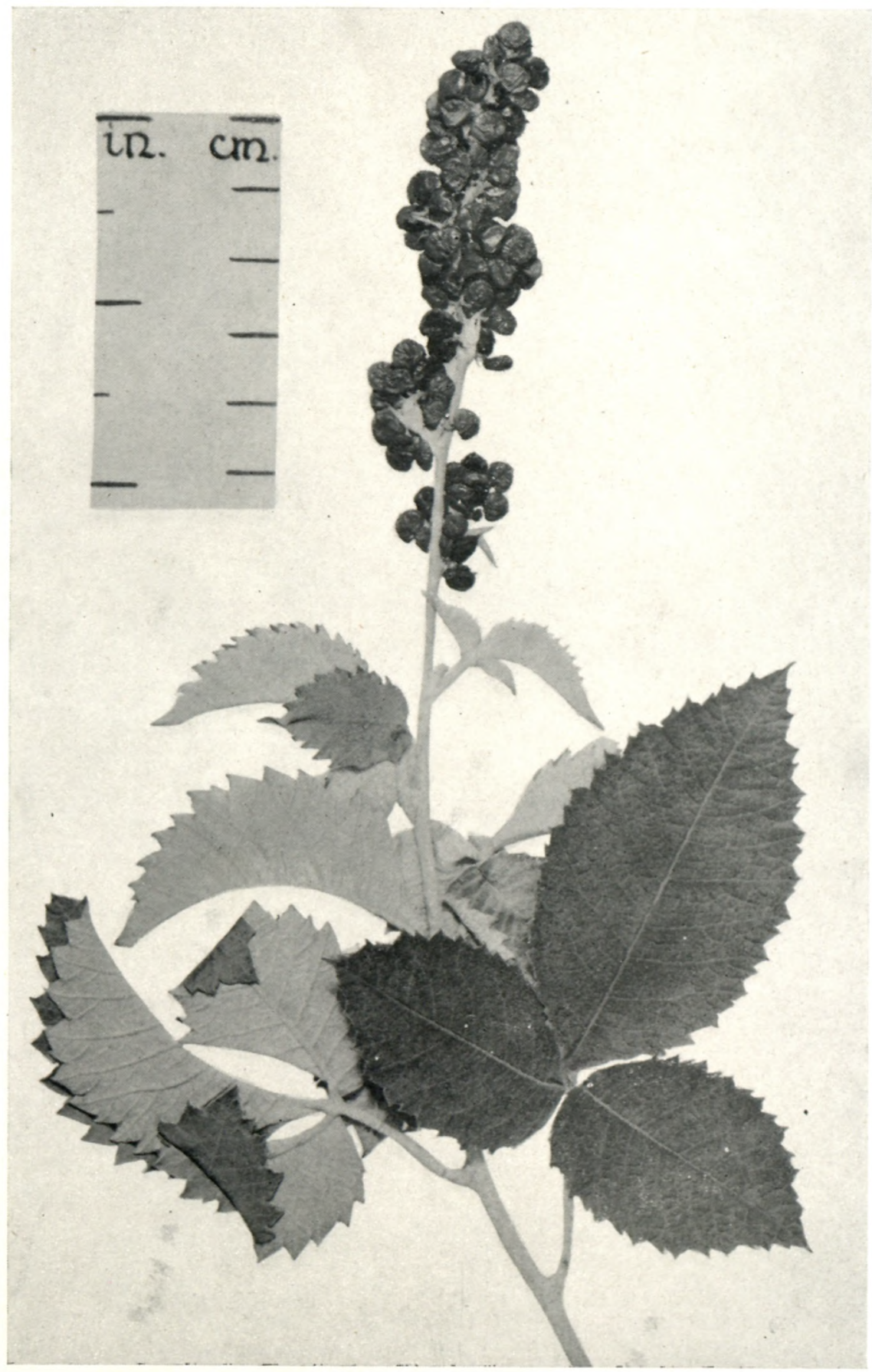

Plate I.-Rhus batophylla L. E. Codd, sp. nov. (Codd and Dyer 7699). 